\title{
Two Newly Obtained Letters by Bedřich Smetana
}

\section{Olga Mojžísová}

Abstract: In 2017 and 2018, the Smetana Museum added two of Bedrich Smetana's letters to its collections. The letter written on 18 April 1859 in Dresden, the day before the death of the composer's first wife Kateřina, was addressed to the piano virtuoso Alexander Dreyschock, and it is a major addition to Smetana's still rather sparse correspondence from the 1850s. The second letter, dated 9 January 1882, is an expression of thanks to the Bivoj Vocal Society in Budyně nad Ohř for the conferring of an honorary membership. The study presents an edition of the two letters including a description of the sources, places them in the context of Smetana's correspondence, and characterises Smetana's relationships with Dreyschock and Bivoj on the basis of the information contained in the letters and the few other sources.

Key words: Bedřich Smetana, Alexander Dreyschock, Bivoj Vocal Society in Budyně nad Ohří, Gothenburg, correspondence

The holdings of the Bedřich Smetana Museum now contain nearly the complete set of sources on the life and works of Bedrich Smetana. Its foundation is Smetana's estate, which the Czechoslovak state purchased for the museum from Smetana's family in 1928. From 1929 to 1932, the composer's heirs gradually turned it over to the museum, and it has been supplemented continuously with new acquisitions of additional original Smetaniana. Smetana's correspondence is one of the most important parts of the Smetana collection and an important source of information about Smetana's life, works, and times. From the estate, however, the museum received correspondence addressed to Smetana for the most part, while correspondence written by Smetana has remained, with some exceptions, the property of the addressees or of their heirs. Only over the decades that followed has the museum managed to add a substantial portion of Smetana's letters to its collection. At present, the museum collection contains a total of 1,153 originals of Smetana's sent and received correspondence. ${ }^{1}$ One now finds only a relatively small portion of this material at other institutions or still in private hands in our country or abroad. A number of sent and received autograph letters that can be proven to have formerly existed are now missing because the traces leading to their

This article has been written within the framework of a project being implemented with the support of the Grant Agency of the Czech Republic (no. 18-20361S): Bedrich Smetana. Korespondence II (1863-1874). Kritická edice. (Correspondence II [1863-1874]. Critical Edition).

1) See ČECHOVÁ, Olga - FOJTÍKOVÁ, Jana: Bedřich Smetana. Inventářfondu S 217 (Bedřich Smetana. Inventory of Collection S 217), National Museum - Czech Museum of Music, Praha 1984, typescript; MOJŽíšovÁ, Olga: Bedřich Smetana. Inventár fondu S 217. Dodatek (Bedřich Smetana. Inventory of Collection S 217. Addendum), National Museum - Czech Museum of Music - Bedřich Smetana Museum, Praha 2011, internal publication. 
owners have gradually disappeared. At least there are old photocopies or copies available of most of them, which the museum has been acquiring systematically over the past decades, and some letters that are now lost were published in print in the past. We therefore know at least about their contents and, in the cases of photocopies, their authentic appearance. Information about the existence of more Smetana correspondence can also be found in written sources (Smetana's diaries, letters) and in the literature, but we usually have no indications about whether these letters still exist or have been lost irretrievably. The findings of materials relating to Smetana in recent decades do, however, document that long-lost sources may reappear after many years, and even discoveries of sources hitherto entirely unknown to the scholarly community are not an exception. ${ }^{2}$

This is also the case with the recently acquired letter by Smetana dated 18 April 1859. It is addressed to Alexander Dreyschock (1818-1869), a piano virtuoso of Czech origin, who defacto instigated Smetana's departure for Gothenburg. The letter does not appear in any of the older lists of Smetana's correspondence, ${ }^{3}$

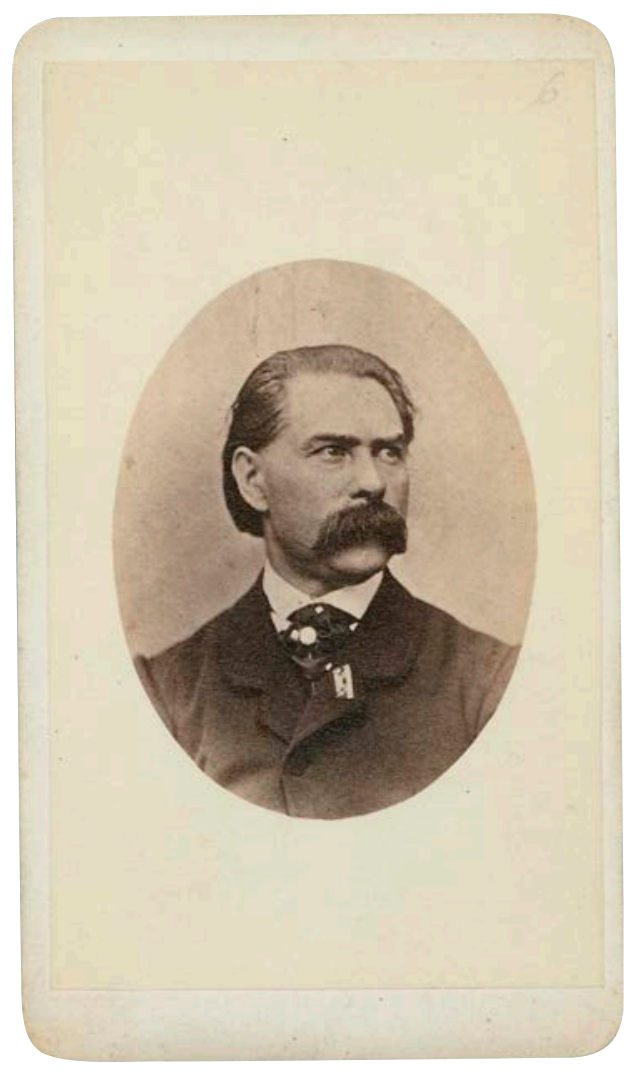

\section{Alexander Dreyschock (1818-1869)}

Photograph, studio of F. Fridrich, Prague, [after 1866] / Fotografie, ateliér F. Fridrich, Praha, [post 1866]

NM-ČMH-MBS 9473 (D XIIa/87) and the first information about it, including excerpts from its contents, appeared in auction catalogues in the 1990s. ${ }^{4}$ The letter was also published in Volume I of the critical edition of Smetana's correspondence, ${ }^{5}$ but only as a torso consisting of excerpts published in those auction catalogues. It appeared again in a catalogue

2) Since the 1990s, the museum has successfully added 74 original letters (57 sent and 17 received) to its Smetana collection.

3) Soupis dopisů Bedricha Smetany chronologický a abecední (Chronological and Alphabetical List of the Letters of Bedřich Smetana), Bedřich Smetana Museum, manuscript 1939-1941; OČADLÍK, Mirko: Soupis dopisů Bedřicha Smetany (List of the Letters of Bedřich Smetana), Miscellanea musicologica, vol. 15, 1960; BARTOŠ, František: Přispěvky k soupisu dopisů Bedřicha Smetany (Contributions to the List of Letters of Bedřich Smetana), Hudební věda (Musicology), vol. 4, 1964, no. 4, pp. 645-682.

4) Music and Continental Manuscripts [...] 16 $16^{\text {th }}-17^{\text {th }}$ May 1991, Sotheby's, London [1991], no. 440, p. 268; Autographen aus allen Gebieten. Auktion am 25. und 26. November 1997 [...] Katalog 667, J. A. Stargardt, Berlin [1997], no. 947, pp. 328-329.

5) MOJŽíŠOVÁ, Olga - POSPÍŠIL, Milan: Bedřich Smetana. Korespondence / Correspondence I. 1840-1862, National Museum - KLP - Koniasch Latin Press, Praha 2016, pp. 132-133 (hereinafter KBS I). 
of the J. A. Stargardt auction house in early 2018, ${ }^{6}$ and this time the National Museum succeeded in purchasing it. ${ }^{7}$ The letter is written in dark ink on three pages of double-sheet stationery measuring $273 \times 222 \mathrm{~mm}$ with the embossed letterhead "HOTEL DE LEIPZIG | W. Kr[?] onefeld | Dresden" in the upper-left corner of both sheets of paper. The two sheets are damaged in the middle of the pages by a vertical crease, and this has resulted in minor losses of text. The letter underwent restoration before the auction.

8"Hochgeehrter Freund!

So gut, als es mir nur möglich ist, schreibe ich tief gebeugt diese Zeilen.

Meine Frau liegt im Sterben. Jeder Augenblick kann mir sie entreißen. - Unter solchen Verhältnissen hat man weder Geschick noch Lust zu brieflichen Mittheilungen. -

Um den Rest ihres Lebens in ihrer Heimath zu verleben, begab sie sich in meiner und der Mutter Begleitung auf den Weg, konnte aber die Mühen und Beschwerlichkeiten einer so weiten Reise nicht aushalten. Wir waren gezwungen, hier in Dresden zu bleiben, und $z u$ warten, bis sie die große Reise ins Jenseits angetreten haben wird. Alles Nähere darüber werde ich Ihnen mündlich mittheilen. -

Die Ursache, warum ich Ihnen, trotz meiner trostlosen Lage, und unterbrochen [durch?] beständige Hilfleistungen für meine arme Frau, [dennoch?] [z] u schreiben mich beeile, || ist ein Fräulein, welches in der Absicht ihre klavieristische Ausbildung bei Ihnen zu e[rlan]gen, von Kopenhagen mit uns bis Dresden fuhr, [von] hier aus aber beinaheverschwunden ist. Im Bahnhofe war sie gezwungen, eine eigene Droschke zu nehmen, weil meine Frau durch das Tragen in den Wagen bewußtlos geworden Iwar/, und unsere ganze Aufmerksamkeit in Anspruch genommen hat. - Sie fuhr wahrscheinlich in ein anderes Hôtel, und befindet sich gewiß jetzt bei Ihnen.? - Ich brauche vielleicht weiter keine Besorgniß deßhalb zu haben? -

Ich schrieb' Ihnen von Gothenburg aus zweimal, ohne irgend eine Antwort erhalten zu haben. - Es ist übrigens leicht möglich, daß weder der eine noch der andere Brief sein Ziel erreichte; denn es geschah das mit zwei Briefen an meine Mutter ebenfalls. Im Winter ist die Versendung der Briefe über die mit Treibeis angefüllten Meeresarme wohl unsicher, und bei der Postverwaltung allemal eine willkommene Ursache zur Ausrede.-

Über meine Gothenburger Wirksamkeit will ich mir daher die mündliche Mittheilung später, bis wir uns sehen, aufsparen, weil ich dazu in dieser Lage absolut untauglich bin. II

Von allen Gothenburgern [F]reunden und Verehrern Ihrer Meisterschaft jederzeit da[s] Beste, Schönste und Herzlichste. Meinen Handkuß Ihrer Frau Gemahlin.

6) Autographen aus allen Gebieten. Auktion 13. und 14. März 2018 [...] Katalog 706, J. A. Stargardt, Berlin [2018], no. 592, pp. 53-54.

7) The letter was entered into the records of the Bedrich Smetana Collection under inventory number S 217/2318.

8) The text of the letter has been reproduced faithfully based on the original. Added words or syllables are in square brackets with a question mark where appropriate. Additions to the text are enclosed between the symbols $\backslash$ /, and the places where the text ends on the individual pages are indicated by $\|$. The transcription does not reflect the original line spacing or dividing of words. 
Mit den freundschaftlichsten Grüßen verbleibe ich stets

werthgeschätzter Freund

$\mathrm{Ihr}$

aufrichtigster

Friedr. Smetana

\section{Dresden den 18 April 1859."}

The letter dates from the period when Smetana was working in Gothenburg, Sweden (18561861). His correspondence from this time is not very extensive, and a number of letters are only known to have existed because they are documented by mentions in the composer's diaries or in other preserved letters. Family correspondence was clearly predominant at the time, while there is rather sporadic documentation of written correspondence with other persons such as figures from artistic circles or with institutions. ${ }^{9}$ The newly obtained letter also mentions another two letters that Smetana wrote to Dreyschock from Gothenburg during previous years. ${ }^{10}$ While the main purpose of Smetana's letter was a message about a woman not further identified who was travelling to see Dreyschock in Prague, it also contains several much more valuable pieces of information, which help reveal at least partially the relationship between these two artists, taking into consideration the other admittedly sparse information.

Smetana had undoubtedly already encountered Dreyschock in Prague's musical circles by the latter half of the 1840s, when he settled in Prague and began to play an active part in Prague's musical life after having completed composition studies under Joseph Proksch. The only concrete information, however, is provided by a mention in the first published biography of Smetana (1863), for which Smetana himself apparently provided biographical material: "At the 'Concordia' artists' association in Prague, Smetana met Alex. Dreyschock, who had heard Smetana frequently and received from Smetana the dedication of the Allegro capriccioso in B Minor."11 The virtuosic Allegro capriccioso was probably composed in 1847. We do not know whether Smetana composed the work with the intention of dedicating it to Dreyschock, or whether he made the dedication later. The specimen with the dedication is not known; all that has been preserved is the first draft, onto which Smetana later added the information

9) Of all sent and received correspondence now on record from the years 1857-1861, the following quantity of letters stands apart from the circle of family correspondence: 1857: from a total of 48 letters, 2 letters in their entirety and 2 that are known only from mentions in other sources; 1858: from a total of 8 letters, 6 letters in their entirety (Smetana was in Gothenburg with his family that year); 1859: from a total of 48 letters, 7 letters in their entirety and 3 from mentions in other sources; 1860: from a total of 47 letters, 2 letters in their entirety and 7 from mentions in other sources; 1861: from a total of 74 pieces of correspondence, 11 in their entirety and 24 from mentions in other sources (that year, however, includes correspondence from Smetana's concert tours and from the period after his return to Bohemia).

10) One still remains lost, while information about the existence of the other (29 March 1857) came from Sotheby's 1991 and 1998 auction catalogues: Sotheby's 1991, see footnote no. 4, no. 439, pp. 266-264; The Collection of George Cosmatos including autograph letters, manuscripts, music and film. Auction 31 3 st 1998 [...], Sotheby's, London [1998], no. 414, p. 126; transcript of excerpts in KBS I, pp. 87-89.

11) R.: Bedřich Smetana, Dalibor, vol. 6, 1863, no. 24, pp. 185-187, here p. 186. 
about the dedication. ${ }^{12}$ There is so far no documentation that Dreyschock ever performed the work. ${ }^{13}$ From these minor indications, one may judge that especially at first the relationship was more like that of a virtuoso of Europe-wide fame on the one hand, and on the other a young pianist and composer who was just beginning to establish social and artistic contacts in Prague's musical circles. We have more concrete information about the relationship between Smetana and Dreyschock from 1856, by which time Smetana was already a respected figure in Prague's musical life. On 27 September, Alexander Dreyschock gave a gala banquet in honour of Franz Liszt, who was in Prague on the occasion of the premiere of his Graner-Messe (Missa solennis zur Erweihung der Basilika in Gran), which he personally rehearsed and conducted in performance at the Saint Vitus Cathedral on 28 September 1856. Among the invited guests from Prague's artistic circles was also Bedřich Smetana, ${ }^{14}$ who spent time together with Liszt several times during the latter's visit to Prague. By then, Smetana must have already been giving serious though to Dreyschock's suggestion that he move to Gothenburg, Sweden. Dreyschock had given concerts there on 25 and 29 May 1856 as part of his concert tour of Sweden, and at the time he was asked by Mrs. Eleonora Dickson, the wife of one of Gothenburg's most important merchants, about whether he might recommend a good piano teacher for Gothenburg. ${ }^{15}$

Smetana decided to go on a concert tour of Sweden - he intended to make appearances in Gothenburg and in Stockholm - and only thereafter did he plan to decide on whether to relocated his centre of activities to Sweden for the following season on the basis of his chances of earning a living and the artistic conditions he found there. He left Prague on 11 October 1856, arrived in Gothenburg on 16 October, ${ }^{16}$ and gave two concerts there (23 October and 2 November 1856). It was not until after the second concert that he made the decision to change his original plans and stay for the season that was already underway. We learn of this from the fragments of his first known letter to Dreyschock dated 29 March 1857, published in auction catalogues (see footnote no. 10). In it, Smetana also thanked him for the friendly advice

12) Autograph NM-ČMH-MBS S 217/1356, on $\mathrm{f}^{\mathrm{r}} \mathrm{I}^{\mathrm{r}}$ at the top on the left in blue pencil is an inscription by Smetana, apparently from the time of a later revision: "Alex. Dreyschock | gewidmet".

13) For more about the composition, see the typescript torso of a thematic list of Smetana's works by František Bartoš, pp. 149-154 (National Museum - Czech Museum of Music, František Bartoš Collection, inv. no. S 48/2958), and also SÉQUARDTOVÁ, Hana (ed.): Bedřich Smetana. Klavírní dílo. Svazek pátý. Skladby virtuosní (Bedřich Smetana. Piano Music. Volume Five. Virtuoso Compositions), Editio Supraphon - Bedřich Smetana Museum, Praha 1973, pp. IX-X and 224.

14) See Mercy's Anzeiger, vol. 3, no. 269, 29 Sept. 1856, p. [1] (Lokal- und Provinzialnachrichten): "Eine Gesellschaft nahmhafter Persönlichkeiten, die Repräsentanz des musikalischen Kunstlebens Prags, als die Direktoren Pitsch und Kittl, die beiden Brüder Skraup, Dr. Ambros, Jules Schulhoff, Regenschori Kreyčy, Smetana u. a. m. hatten sich unter dem Vortritt und der Anregung Alex. Dreyschocks eingefunden, um den in unseren musikalischen Kreisen so hochwillkommenen Fr. Liszt auf würdige Weise einen Beweis allseitiger Verehrung zu zollen."

15) The prevailing opinion in Gothenburg was supposedly that by making this recommendation, Dreyschock wished to rid himself of Smetana as a competitor in Prague. See KRAUS, Arnošt: Smetana v Göteborgu (Smetana in Gothenburg), J. Otto, Praha 1925, pp. 65-66, 78-79.

16) See the report in the newspaper Göteborgs Handels- och Sjöfarts- Tidning no. 243, 17 Oct. 1856, p. [3]: "An artist of the piano, Mr. F. Smetana, has come to our city from Prague at the recommendation of Mr. Dreyschock firstly to give concerts, but if the circumstances should appear favourable, he might also work here for some time." (The Czech translation from Swedish is by Dagmar Hartlová. The English version is based on her translation.) 
that he settle in Gothenburg, and in the following parts of the letter, he seems to have given a quite exhaustive description of his artistic activities there. From the overall tone of the letter and from the form of address ("Verehrter Freund"), one may deduce there must been friendly personal relations between the two artists at the time and undoubtedly already in Prague before Smetana's departure. This is, of course, also suggested by the second letter, published above, dated 18 April 1859, in which Smetana, by describing his current tragic family situation, also reveals to Dreyschock his emotional state at the moment, and he leaves a more detailed account of the events mentioned in the letter for a future personal meeting. It was in Dresden that he wrote the letter the day before the death of his first wife Katerina, whom he was swiftly returning to Prague from Gothenburg together with his mother-in-law Anna Kolářová. On the other hand, the mention of two letters unanswered by Dreyschock would indicate that there was probably more communication coming from Smetana's direction, whether out of gratitude or a desire to maintain what was for him possibly an important contact, moreover with a person who had some knowledge of the situation in Gothenburg. Dreyschock, however, clearly did not need to communicate with Smetana. Smetana's rationalisation that the delivery of mail was more complicated during the winter months can be viewed as a possible real reason, but also as "diplomatically" smoothing over a rather accusatory undertone. This unilateral imbalance is also confirmed to a certain extent by mentions of the last documented written communication between these two artists from late April 1862 (the letters themselves are lost). Smetana was back in Gothenburg from March until early May in order to improve his financial situation because upon his return to Prague, he did not find a solid source of income and was living only from his Swedish savings. In Gothenburg he taught lessons, gave two concerts, and also made plans for concerts in Christiania (now Oslo), Norway, and in Copenhagen, Denmark. Near the end of his stay, he received a letter on 27 April 1862 from Dreyschock, who happened to be making an appearance in Copenhagen ${ }^{17}$, asking for support for the giving of his concert in Gothenburg: "Brief von Alex[ander] Dreyschock aus Kopenhagen, worin er seine Absicht nach Gothenburg zu Conzerten zu kommen ausspricht, und meine Unterstützung ersucht." ${ }^{\prime 1}$ In the following comments, Smetana's reaction to his request is quite negative: "Zu Hause in Prag kümmert er sich wenig um mich, er sieht aus stolzer Höhe seines Ruhmes auf mich herab. Indessen kann ich hier nichts thun, so gerne ich bereit dazu bin; aber ich konnte mir selbst nicht viel helfen, geschweige Anderen." ${ }^{19}$ Even if Smetana's spontaneous reaction seems to capture accurately the nature of Dreyschock's relationship with him, in

17) For more about Dreyschock's concerts in Copenhagen, see the report in Dalibor, vol. 5, 1862, no. 17, p. 128.

18) Smetana's diary, 1861/62, 27 April 1862, p. 22 (NM-ČMH-MBS S 217/1099).

19) Smetana left Gothenburg on about 3 May. From the letter from Rosa Valentin to Bettina Smetanová dated 4 July 1862 (NM-ČMH-MBS S 217/1970), we know that Dreyschock did not come to Gothenburg until June 1862. On 12 June he appeared at a matinee that was not very well attended, and he got a warm reception mainly in the homes of Smetana's closest friends there: "[...] er war vier Tage hier, spielte viel bei Frau Benecke, auch mehre à quatre mains mit ihr, er sagte daß es ihm wohlthue zu hören wie beliebt Herr Smetana hier ist, er war auch bei uns, u[nd] probierte unser Instrument, mein Mann sagte ihm, daß er würde ihm gern, nur aus Dankbarkeit das Instrument leihen, weil er vor Jahren Herrn Smetana dazu überredete nach Gothenburg zu gehen.” 
view of the friendly, even somewhat intimate tone in both of his previous letters, one must view this extreme emotion with some caution. In adverse situations, Smetana's reactions were often blunt and not entirely objectively, and a certain resentment over the failure of his original concert plans may also have played a part. He was forced to abandon his idea of giving a concert in Copenhagen because dates had already been reserved there at the same time for concerts being given by other far more famous artists, Dreyschock among them. ${ }^{20}$ Smetana was furthermore disappointed that the attendance of and earnings from his own concerts in Gothenburg did not entirely meet his expectations, and making reference to the local situation, he also apparently replied to Dreyschock: "Antwort an Dreyschock geschickt, wobei ich die trostlosen Aspekten der Gothenburger mus[ikalischen] Zustände ihm schilderte." ${ }^{21}$

While Smetana's letter to Dreyschock dated 18 April 1859 was a discovery of a previously unknown source, Smetana's second letter dated 9 January 1882 addressed to the Bivoj Vocal Society in Budyně nad Ohří, which was successfully purchased in 2017, is the rediscovery of an original after many years. The text of the letter had already appeared in 1885 in the journal Dalibor, ${ }^{22}$ which continually published a selection of ninety-five of Smetana's letters from 1885 to 1887 . The owners of the letters at the time had provided them to the editorial staff of the journal for this purpose. This letter had been lent directly by the Bivoj Vocal Society, as is shown by the inscription on f. 2': "Dear | editors of the mus[ic] journal | Dalibor'| in Prague | Please send the original of this $\mid$ letter back to us $\mid$ with profound respect $\mid V$. Nešvera $\mid$ currently the treasurer of 'Bivoj' ". In the manuscript list of Smetana's letters at the Smetana Museum (see footnote no. 3), there is a comment in pencil that the letter is owned by the association Bivoj, but we do not know whether this information was then verified. Mirko Očadlík looked for it in 1960 while preparing his list of Smetana's letters. ${ }^{23}$ From the published list, it is apparent that he did not

20) See the letters Lose, Carl Christian: Smetana, Bedřich, 9 April 1862; Smetana, Bedřich: Smetanová, Bettina, 11-19 April 1862 (NM-ČMH-MBS S 217/724 and 158; KBS I, pp. 369-370, 372-379).

21) Smetana's diary, 1861/62, 28 April 1862 (see footnote no. 18). He makes similar comments about Dreyschock's request in a letter to his wife Bettina dated 24 - 30 April 1862 (KBS I, pp. 386-387): "Alex. Dreyschock hat aus Kopenhagen an mich geschrieben, daß er herkommen will, um zu konzertiren, und ich möchte ihn durch Rath etc. unterstützen. Was kann ich thun? Ich bin froh, daß meine eigenen Conzerte so passabel ausfielen, und habe wenig Einfluß mehr auf die hiesigen Leute."

22) Smetanovy dopisy (Smetana's Letters), Dalibor, vol. 7, 1885, no. 47, p. 459.

23) The answer to his inquiry from the former Janda Museum in Budyně nad Ohři has been preserved: "[...] The letter is not in the archives of our museum, but it might be in the municipal archives. You see, when Bivoj ceased its activities (long ago), Bivoj's documents and music were kept at the municipal archives at the suggestion of the archivist Mr. Janda. When it resumed its activities, their things from the archives were given back to them. Some years later their activities ceased again, but that time their things were not put into the archives. They stayed in a cabinet in the public house where Bivoj had a room, and during the Protectorate the materials found themselves in places that were accessible to irresponsible persons, and no one knows who did what with them. The members of the museum society took what remained to the municipal archives until 1958. [...] They must be looked for it in those archives. It is possible that when the archivist Mr. Janda turned over the Bivoj materials when their activities were resumed for the first time, he may have turned over only their music and have kept the written documents in the archives." Kept with the materials for the edition of Smetana's correspondence at the Bedřich Smetana Museum under ref. no. 283/90 MČ H 1. 
succeed in finding the original. ${ }^{24}$ Likewise, when verifying information about provenience as part of the preparations for the critical edition of Smetana's correspondence in the early 1990s, the museum received a negative answer concerning the existence of this letter. ${ }^{25}$

The letter is written in dark ink on the first page of double-sheet stationery measuring $230 \times 145 \mathrm{~mm}$. It is in Josef Srb's hand; Smetana merely signed it. ${ }^{26}$

"To the esteemed members of the committee of the vocal association

\section{'Bivoj' \\ in Budynè!}

I wish to express my most heartfelt thanks for the special distinction I have received by having been made an honorary member of the renowned association 'Bivoj'.

It is all the greater pleasure for me to have received this honour from such an exuberant association, which is outstanding for the success of its activities in every respect. I wish your great association success most abundant, and I would ask that the esteemed committee express my cordial greetings to all of the gentlemen members!

Respectfully yours,

Prague, 9 January 1882.

Bedř. Smetana”

The date and contents of this letter place it in an entirely different context within Smetana's correspondence, which had grown with respect to both volume and diversity of content by 1882. From Smetana's return from Sweden until the mid-1870s, i.e. the time of his most intensive activities in Prague's musical life, his written contacts still were not terribly extensive, because he could handle most personal and professional matters in Prague in person, and family correspondence was limited mostly to the summer months, which his family spent in the countryside. Only after he went deaf (autumn of 1874) did written contact become his only means of communicating with those closest to him and with the public, leading to a sharp increase in the quantity of Smetana's correspondence, culminating in the $1880 \mathrm{~s} .{ }^{27}$ By then, Smetana had attained the standing of the nationally recognised father of Czech music, and especially on the occasions of certain official tributes and celebrations held in his honour, he received many congratulatory telegrams and letters. And it was this very type of correspondence that significantly contributed to the suddenly increased quantity of correspondence during the years in question. The granting of honorary memberships, further confirmed in some cases by

24) Očadlík's list (see footnote no. 3), p. 100, states that the letter is located in the archives of the association Bivoj, but it is unavailable at present.

25) See the letter from the District Archives in Litoměrice based in Terezín, dated 6. Dec. 1990: "The materials from the collection of the Bivoj Vocal Society in Budyně n. O. are in our keeping. The letter in question, however, is not among them, and we know nothing about its fate." Kept with the materials for the edition of Smetana's correspondence at the Bedřich Smetana Museum under ref. no. 283/90 MČH 1.

26) The letter was entered into the records of the Bedrich Smetana Collection under inventory no. S 217/2319.

27) According to the current state of the documentation of Smetana's correspondence, from 1863 to 1873 the total number of now known pieces of correspondence varied within the range of 27 to 45 items per year, in 1874 the number is 84 items, from 1875 to 1879 the number of items per year is in the range of $67-125$, and in the years 1880 to 1882 there are 271, 221, and 244 items of correspondence respectively. 
the presentation of an honorary diploma, was a relatively common way that various institutions and especially associations expressed their recognition and respect to deserving persons. Twenty-eight honorary diplomas have been preserved in Smetana's estate, ${ }^{28}$ while a number of other associations merely informed him in writing about the granting of honorary memberships. This was also the case with the association Bivoj in Budyně nad Ohří, which informed Smetana about the resolution of its general meeting ${ }^{29}$ by telegram dated 31 December 1881: "Honoured master! The general meeting of the vocal association 'Bivoj' in Budyně nad Ohří, in recognition of your immortal contribution to Czech music, has unanimously made you an honorary member of the association. The Bivoj Committee." ${ }^{30}$ Smetana's letter dated 9 January is a response to this notification. The fact that it had been written and undoubtedly also formulated by Josef Srb was nothing unusual for this period. Srb, with whom Smetana almost always lived during his stays in Prague, not only was his close, intimate friend, but also served to some extent as his private secretary. He acted and corresponded directly on Smetana's behalf with certain institutions, and in that capacity he sometimes handled such official correspondence. He also prepared or corrected the texts of some of Smetana's letters, among other things. From 7 to 28 January 1882, Smetana was staying in Prague, ${ }^{31}$ and he undoubtedly brought along the telegram from Budyně addressed to Jabkenice to be dealt with, then he signed the response formulated by Srb.

Making Smetana an honorary member was not the only expression of honour and respect the composer received from the Budyně association Bivoj. In January 1880 Bivoj sent a congratulatory telegram and contributed the sum of 10 gulden to a fundraiser in the composer's honour on the occasion of a gala concert for the fiftieth anniversary of Smetana's concert activities, which had been organised jointly by the Czech associations Umělecká beseda (Artists' Society), Hlahol (a vocal society), and the Akademický čtenářský spolek (Academic Reading Society). ${ }^{32}$ It also sent congratulatory telegrams on 5 May 1882 for the $100^{\text {th }}$ performance of Prodaná nevěsta (The Bartered Bride) and on 2 March 1884 for Smetana's $60^{\text {th }}$ birthday, ${ }^{33}$ then finally on 13 May a telegram of condolences upon Smetana's death. ${ }^{34}$

Both newly acquired letters are an important enrichment of the existing collection of Smetana's correspondence. The first adds to the modest quantity of the composer's written correspondence from the $1850 \mathrm{~s}$ and is important documentation of his contacts with prominent figures of the musical circles of the day. The second letter adds to the large collection of

28) He received three diplomas already in the 1860s, 8 in the '70s, and 17 from 1880 to 1884.

29) It took place on 30 December 1881; see Urbánkův Věstník bibliografický (Urbánek’s Bibliographical Bulletin), vol. 3, 1882, no. 1, p. 9 .

30) The original is privately owned; the copy at the MBS is under acquisition no. 34/91.

31) Notes written in the calendar Vlast' (Homeland) for 1882, January (NM-ČMH-MBS S 217/1123).

32) See the printed list of all contributions towards the gift in his honour (Semily State District Archives, archives of the vocal association Jizeran). More in: MOJŽíŠovÁ, Olga: Čestné finanční dary Bedřichu Smetanovi, in: Miscellanea z výroční konference České společnosti pro hudební vědu 2008. Fenomén mecenášstvív hudební kultuře (Honorary Financial Gifts to Bedřich Smetana, Miscellanea from the annual conference of the Czech Musicology Society in 2008. The Phenomenon of Patronage in Musical Culture), Czech Musicological Society - Institute of Ethnology of the Czech Academy of Sciences - Nakladatelství Agora, Praha 2010, pp. 78-83.

33) For the originals, see footnote no. 30.

34) See the list of telegrams of condolences from Czech cities published in Dalibor vol. 6, 1884, no. 20, p. 195. 
correspondence related to official honours that Smetana was receiving near the end of his life. Both discoveries give us hope for possible future "finds" of now missing or previously unknown letters, which could further expand the collection of Smetanas sent and received correspondence.

Address: Olga Mojžišsová, Muzeum Bedřicha Smetany, Novotného lávka 1, 11000 Praha 1, Czech Republic

E-mail: olga_mojzisova@nm.cz

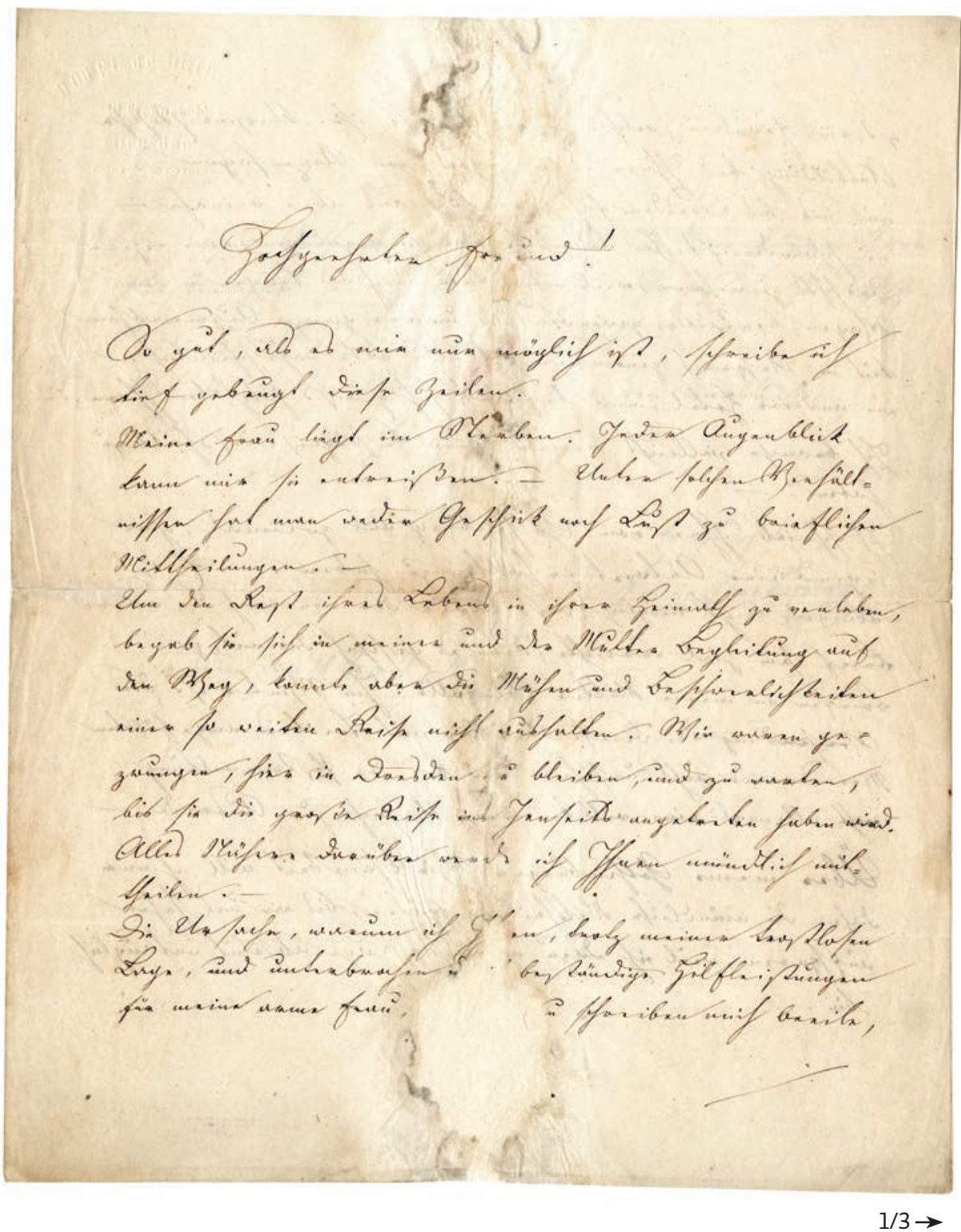




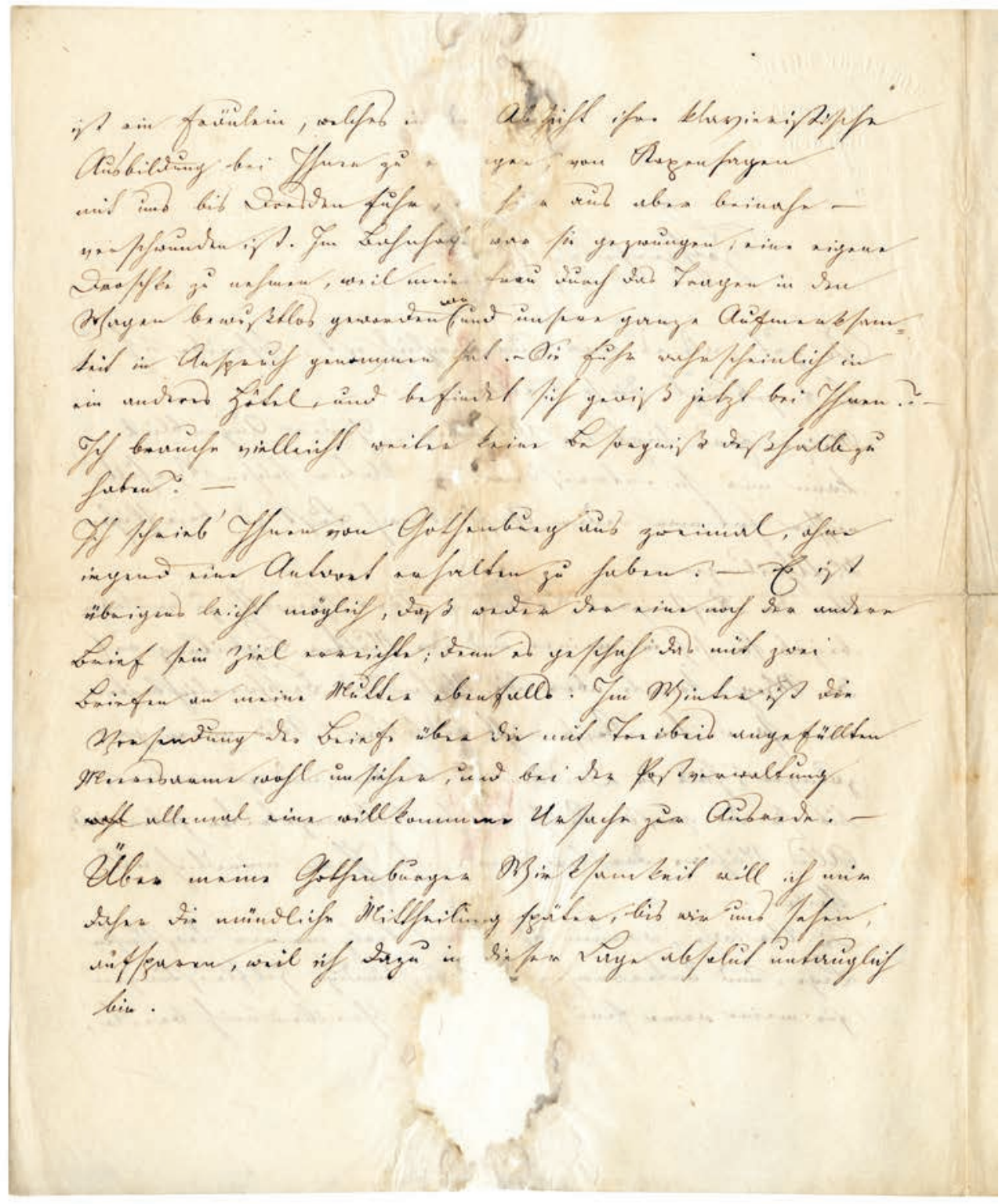

Bedřich Smetana to Alexander Dreyschock / Bedřich Smetana Alexandru Dreyschockovi Autograph, Dresden, 18 April 1859 / Autograf, Drážd'any, 18. 4. 1859

NM-CMH-MBS S 217/2318 


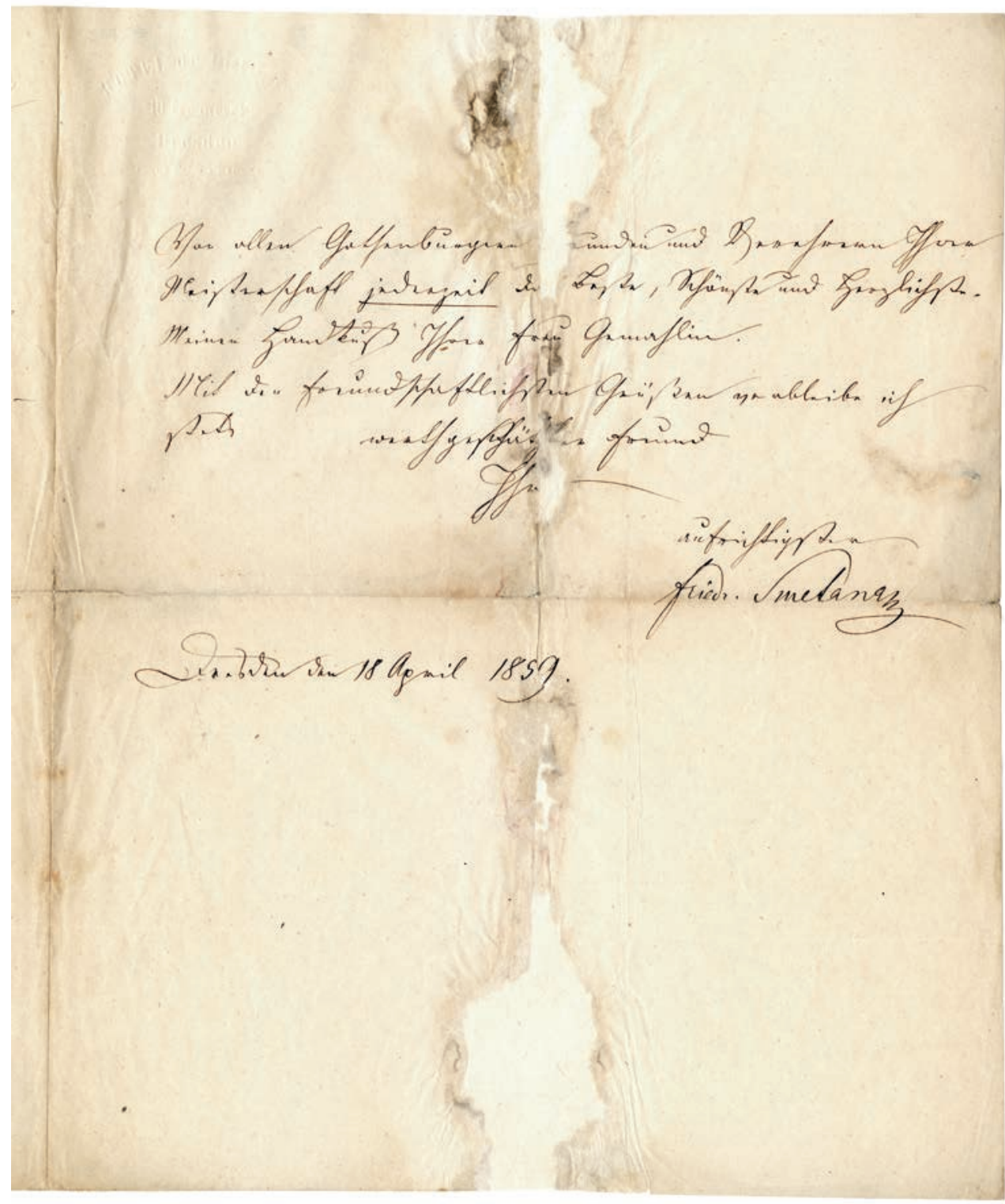




\section{Dua nově získané dopisy Bedřicha Smetany}

\section{Olga Mojžísová}

Muzeum Bedřicha Smetany v současnosti spravuje téměř kompletní pramenný soubor k životu a dílu Bedřicha Smetany. Jeho základem je Smetanova pozůstalost, kterou v roce 1928 pro muzeum zakoupil od rodiny československý stát. V letech 1929-1932 byla skladatelovými dědici postupně předána do muzea a to ji pak průběžně doplňovalo novými akvizicemi o další originální smetaniana. Jednu z nejvýznamnějších součástí smetanovského fondu a důležitý zdroj informací ke Smetanovu životu, dílu a době představuje jeho korespondence. S pozůstalostí však přišla do muzea především korespondence adresovaná Smetanovi, kdežto korespondence psaná Smetanou zůstala až na výjimky nadále v majetku adresátů, resp. jejich dědiců. Teprve v následujících desetiletích se muzeu podařilo do sbírek postupně získat také podstatnou část Smetanových dopisů. V současnosti muzejní fond obsahuje celkem 1153 originálů Smetanovy odeslané a přijaté korespondence. ${ }^{1}$ Jen její relativně malá část se tak nachází v jiných institucích nebo ještě zůstává v soukromém majetku u nás i v zahraničí. Řada autografů odeslaných a přijatých dopisů, které kdysi prokazatelně existovaly, je však dnes nezvěstná, nebot’ se stopy k jejich majitelům postupně vytratily. Od většiny z nich jsou $\mathrm{k}$ dispozici alespoň staré fotokopie či opisy, které muzeum v předešlých desetiletích celkem systematicky pořizovalo, a některé dnes nezvěstné dopisy byly $\mathrm{v}$ minulosti vydány tiskem. Známe tak alespoň jejich obsah a v př́padě fotokopií i jejich autentickou podobu. $\mathrm{O}$ existenci další Smetanovy korespondence lze nalézt informace také v písemných pramenech (Smetanovy deníky, dopisy) a v literatuře. Nemáme ale většinou žádné indicie o tom, zda tyto dopisy ještě existují, nebo jsou již nenávratně ztraceny. Smetanovské nálezy z posledních desetiletí však dokládají, že se po letech mohou znovu objevit též dlouho nezvěstné prameny, a výjimkou nejsou ani objevy pramenů badatelské veřejnosti dosud zcela neznámých. ${ }^{2}$

To je i př́pad nedávno získaného Smetanova dopisu z 18. dubna 1859. Je adresován klavírnímu virtuosovi českého původu Alexandru Dreyschockovi (1818-1869), který de facto inicioval Smetanův odchod do Göteborgu. Neevidoval jej žádný ze starších soupisů Smetanovy

Článek vznikl v rámci projektu řešeného s podporou Grantové agentury ČR (č. 18-20361S): Bedřich Smetana. Korespondence II (1863-1874). Kritická edice.

1) Viz ČECHOVÁ, Olga - FOJTÍKOVÁ, Jana: Bedřich Smetana. Inventářfondu S 217, Národní muzeum - Muzeum české hudby, Praha 1984, strojopis; MOJŽí̌̌oVÁ, Olga: Bedřich Smetana. Inventář fondu S 217. Dodatek, Národní muzeum - České muzeum hudby - Muzeum Bedřicha Smetany, Praha 2011, interní tisk.

2) Od devadesátých let 20. století se muzeu podařilo smetanovský fond rozširíit o 74 originálních dopisů (57 odeslaných a 17 príjatých). 
korespondence, ${ }^{3}$ první informace o něm, včetně úryvků z jeho obsahu, přinesly až aukční katalogy v devadesátých letech 20. století. Jen jako torzo složené z úryvků uveřejněných v těchto aukčních katalozích byl dopis publikován také v 1. svazku kritické edice Smetanovy korespondence. ${ }^{5}$ Znovu se objevil v katalogu aukční síně J. A. Stargardt začátkem roku $2018^{6}$ a tentokrát se jej Národnímu muzeu podařilo zakoupit. ${ }^{7}$ Dopis je psán tmavým inkoustem na třech stranách dvojlistu dopisního papíru o rozměrech $273 \times 222$ mm s vytlačenou hlavičkou „Hotel de Leipzig | W. Kr[?] onefeld | Dresden“ v levém horním rohu obou listů. Oba listy jsou ve svislém přehybu uprostřed stran poškozeny, čímž došlo k drobným ztrátám textu. Dopis byl ještě před aukcí restaurován.

\section{${ }^{8}$ „Hochgeehrter Freund!}

So gut, als es mir nur möglich ist, schreibe ich tief gebeugt diese Zeilen.

Meine Frau liegt im Sterben. Jeder Augenblick kann mir sie entreißen. - Unter solchen Verhältnissen hat man weder Geschick noch Lust zu brieflichen Mittheilungen. -

Um den Rest ihres Lebens in ihrer Heimath zu verleben, begab sie sich in meiner und der Mutter Begleitung auf den Weg, konnte aber die Mühen und Beschwerlichkeiten einer so weiten Reise nicht aushalten. Wir waren gezwungen, hier in Dresden zu bleiben, und $z u$ warten, bis sie die große Reise ins Jenseits angetreten haben wird. Alles Nähere darüber werde ich Ihnen mündlich mittheilen. -

Die Ursache, warum ich Ihnen, trotz meiner trostlosen Lage, und unterbrochen [durch?] beständige Hilfleistungen für meine arme Frau, [dennoch?] [z] u schreiben mich beeile, || ist ein Fräulein, welches in der Absicht ihre klavieristische Ausbildung bei Ihnen zu e[rlan]gen, von Kopenhagen mit uns bis Dresden fuhr, [von] hier aus aber beinaheverschwunden ist. Im Bahnhofe war sie gezwungen, eine eigene Droschke zu nehmen, weil meine Frau durch das Tragen in den Wagen bewußtlos geworden \war/, und unsere ganze Aufmerksamkeit in Anspruch genommen hat. - Sie fuhr wahrscheinlich in ein anderes Hotel, und befindet sich gewiß jetzt bei Ihnen.? - Ich brauche vielleicht weiter keine Besorgniß deßhalb zu haben? -

Ich schrieb' Ihnen von Gothenburg aus zweimal, ohne irgend eine Antwort erhalten zu haben. - Es ist übrigens leicht möglich, daß weder der eine noch der andere Brief sein

3) Soupis dopisů Bedřicha Smetany chronologický a abecední, Museum Bedřicha Smetany, rukopis 1939-1941; OČADLÍK, Mirko: Soupis dopisů Bedřicha Smetany, Miscellanea musicologica, sv. 15, 1960; BARTOŠ, František: Př́spěvky k soupisu dopisů Bedřicha Smetany, Hudební věda, roč. 4, 1964, č. 4, s. 645-682.

4) Music and Continental Manuscripts [...] 16 $16^{\text {th }}-17^{\text {th }}$ May 1991, Sotheby's, London [1991], č. 440, s. 268; Autographen aus allen Gebieten. Auktion am 25. und 26. November 1997 [...] Katalog 667, J. A. Stargardt, Berlin [1997], č. 947, s. 328-329.

5) MOJŽÍŠOVÁ, Olga - POSPÍŠIL, Milan: Bedřich Smetana. Korespondence / Correspondence I. 1840-1862, Národní muzeum - KLP - Koniasch Latin Press, Praha 2016, s. 132-133 (dále jen KBS I).

6) Autographen aus allen Gebieten. Auktion 13. und 14. März 2018 [...] Katalog 706, J. A. Stargardt, Berlin [2018], č. 592, s. 53-54.

7) Do fondu Bedřich Smetana byl dopis zaevidován pod inventárním číslem S 217/2318.

8) Text dopisu je reprodukován věrně podle originálu, doplněná slova či hlásky jsou v hranatých závorkách, př́padně s otazníkem, vsuvky do textu jsou vyznačeny $\backslash$ /, konce textu na jednotlivých stranách originálu $\|$, řádkování originálu a dělení slov se nezohledňuje. 
Ziel erreichte; denn es geschah das mit zwei Briefen an meine Mutter ebenfalls. Im Winter ist die Versendung der Briefe über die mit Treibeis angefüllten Meeresarme wohl unsicher, und bei der Postverwaltung allemal eine willkommene Ursache zur Ausrede. -

Über meine Gothenburger Wirksamkeit will ich mir daher die mündliche Mittheilung später, bis wir uns sehen, aufsparen, weil ich dazu in dieser Lage absolut untauglich bin. II

Von allen Gothenburgern [F]reunden und Verehrern Ihrer Meisterschaft jederzeit da[s] Beste, Schönste und Herzlichste. Meinen Handkuß Ihrer Frau Gemahlin.

Mit den freundschaftlichsten Grüßen verbleibe ich stets

werthgeschätzter Freund

Ihr

aufrichtigster

Friedr. Smetana

Dresden den 18 April 1859.“

Dopis spadá do období Smetanova působení ve švédském Göteborgu (1856-1861). Z té doby není jeho korespondence ještě př́liš rozsáhlá a existence řady dopisů je navíc doložena pouze zmínkami ve skladatelových denících, př́ípadně $\mathrm{v}$ dochovaných dopisech. Jednoznačně tehdy převažovala korespondence rodinná, zatímco písemný styk s jinými osobnostmi, např. z uměleckého světa nebo s institucemi, je doložen poměrně sporadicky. ${ }^{9}$ Nově získaný dopis navíc obsahuje zmínku o dalších dvou listech, které Smetana v předchozích letech Dreyschockovi z Göteborgu napsal. ${ }^{10}$ Hlavním účelem Smetanova dopisu byla sice zpráva o blíže neidentifikované dámě cestující za Dreyschockem do Prahy, vedle ní je zde však řada mnohem cennějších údajů, díky nimž lze s přihlédnutím k dalším, byt dosti sporadickým informacím alespoň částečně poodhalit vztah těchto dvou umělců.

Smetana se s Dreyschockem nepochybně setkával v pražských hudebních kruzích již od 2. poloviny čtyřicátých let 19 . století, když se po absolutoriu kompozičních studií u Josepha Proksche usadil v Praze a začal se aktivně uplatňovat v pražském hudebním životě. Jedinou konkrétní informaci však poskytuje zmínka v prvním uveřejněném Smetanově životopise z roku 1863, k němuž zřejmě sám poskytl biografické podklady: „V umělecké jednotě ,Concordia'v Praze poznal Smetana Alex. Dreyschocka, který jej častěji poslouchal a prijimul od něho mu věnovanou Allegro capriccioso H-moll. ${ }^{\text {‘1 }}$ Virtuózní Allegro capriccioso vzniklo pravděpodobně v roce 1847. Zda Smetana skladbu komponoval již s úmyslem věnovat ji

9) Ze všech dnes evidovaných odeslaných a přijatých korespondenčních sdělení z let 1857-1861 stojí mimo okruh rodinné korespondence následující počty dopisů: 1857: z celkem 48 dopisů 2 dopisy $v$ plném znění + 2 známé jen ze zmínek z jiných pramenů; 1858: z celkem 8 dopisů 6 dopisů v plném znění ( $v$ tomto roce byl Smetana $v$ Göteborgu s rodinou); 1859: $z$ celkem 48 dopisů 7 dopisů v plném znění a 3 ze zmínek z jiných pramenů; 1860: z celkem 47 dopisů 2 dopisy v plném znění +7 ze zmínek z jiných pramenů; 1861: z celkem 74 sdělení 11 v plném znění + 24 ze zmínek z jiných pramenů (tento rok však již zahrnuje i korespondenci ze Smetanových koncertních cest a z doby po návratu do Čech).

10) Jeden zůstává nadále nezvěstný, o existenci druhého (29. 3. 1857) přinesly informaci až aukční katalogy Sotheby's z let 1991 a 1998: Sotheby's 1991 viz pozn. 4, č. 439, s. 266-264; The Collection of George Cosmatos including autograph letters, manuscripts, music and film. Auction $31^{\text {st }}$ March 1998 [...], Sotheby's, London [1998], č. 414, s. 126; přepis úryvků v KBS I, s. 87-89.

11) R.: Bedřich Smetana, Dalibor, roč. 6, 1863, č. 24, s. 185-187, zde s. 186. 
Dreyschockovi a nebo tak učinil až později, nevíme. Dedikační exemplář není znám, dochoval se pouze první zápis, na němž je údaj o věnování Smetanou poznamenán dodatečně. ${ }^{12}$ Není zatím doloženo, že by Dreyschock tuto skladbu někdy provedl. ${ }^{13} \mathrm{Z}$ těchto drobných indicií lze usuzovat, že zejména zpočátku šlo spíše o vztah virtuosa evropského věhlasu a na druhé straně mladého pianisty a skladatele, který si teprve začínal budovat společenské a umělecké kontakty v pražských hudebních kruzích. Další konkrétní informace ke vztahu Smetana Dreyschock máme z roku 1856, kdy byl již Smetana v pražském hudebním životě respektovanou osobností. 27. září uspořádal Alexander Dreyschock slavnostní banket na počest Franze Liszta, jenž v Praze pobýval u př́ležitosti premiéry své Graner-Messe (Missa solennis zur Erweihung der Basilika in Gran), kterou osobně nastudoval a řídil v chrámu sv. Víta 28. září 1856. Mezi pozvanými hosty z pražských uměleckých kruhů byl i Bedřich Smetana, ${ }^{14}$ který se s Lisztem za jeho pobytu v Praze často stýkal. Tehdy se již Smetana také musel intenzívně zabývat Dreyschockovým doporučením přenést své působiště do švédského Göteborgu. Dreyschock zde koncertoval 25. a 29. května 1856 v rámci své koncertní cesty do Švédska a byl tehdy požádán paní Eleonorou Dickson, manželkou jednoho z nejvýznamnějších göteborských obchodníků, zda by mohl do Göteborgu doporučit kvalitního učitele klavíru. ${ }^{15}$

Smetana se rozhodl odjet do Švédska na koncertní cestu - zamýšlel vystoupit v Göteborgu a ve Stockholmu - a teprve podle toho, jaké zde najde existenční a umělecké podmínky, se hodlal rozhodnout, zda své působiště od následující sezóny do Švédska přesune. Z Prahy odcestoval 11. října 1856, 16. října přijel do Göteborgu ${ }^{16}$ a uspořádal zde dva koncerty (23. řína a 2. listopadu 1856). Změnit původní plány a setrvat již ve stávající sezóně se rozhodl teprve po druhém $\mathrm{z}$ nich. O tom se dozvídáme z fragmentů prvního známého dopisu Dreyschockovi z 29. 3. 1857, publikovaných v aukčních katalozích (viz pozn. 10). Smetana mu v něm také děkuje za přátelskou radu usadit se v Göteborgu a v následujících partiích zřejmě dosti obšírně popisoval své zdejší umělecké aktivity. Z celkového tónu dopisu a oslovení „Verehrter Freund“ lze usuzovat, že mezi oběma umělci musel v té době, a nepochybně tedy už v Praze před Smetanovým odjezdem, panovat přátelský osobní vztah. Tomu

12) Autograf NM-ČMH-MBS S 217/1356, na f. $1^{r}$ vlevo nahoře modrou tužkou Smetanův prípis patrně z doby pozdější revize: „Alex. Dreyschock | gewidmet“.

13) Více ke skladbě viz strojopisné torzo tematického soupisu Smetanových děl od Františka Bartoše, s. 149-154 (Národní muzeum - České muzeum hudby, fond František Bartoš, inv. č. S 48/2958), též SÉQUARDTOVÁ, Hana (ed.): Bedřich Smetana. Klavírní dílo. Svazek pátý. Skladby virtuosní, Editio Supraphon Museum Bedřicha Smetany, Praha 1973, s. IX-X a 224.

14) Viz Mercy’s Anzeiger, roč. 3, č. 269, 29. 9. 1856, s. [1] (Lokal- und Provinzialnachrichten): „Eine Gesellschaft nahmhafter Persönlichkeiten, die Repräsentanz des musikalischen Kunstlebens Prags, als die Direktoren Pitsch und Kittl, die beiden Brüder Skraup, Dr. Ambros, Jules Schulhoff, Regenschori Kreyčy, Smetana u. a. m. hatten sich unter dem Vortritt und der Anregung Alex. Dreyschocks eingefunden, um den in unseren musikalischen Kreisen so hochwillkommenen Fr. Liszt auf würdige Weise einen Beweis allseitiger Verehrung zu zollen."

15) V Göteborgu údajně převažovalo mínění, že se Dreyschock tímto doporučením chtěl v Praze zbavit Smetany jako konkurenta. Viz KRAUS, Arnošt: Smetana v Göteborgu, J. Otto, Praha 1925, s. 65-66, 78-79.

16) Viz zpráva v deníku Göteborgs Handels- och Sjöfarts- Tidning č. 243, 17. 10. 1856, s. [3]: „Do našeho města přibyl klavírní umělec, pan F. Smetana z Prahy, který k nám príijel na doporučení pana Dreyschocka předně koncertovat, ale pokud se okolnosti budou jevit příznivě, též nějakou dobu zde působit." (Ze švédštiny přeložila Dagmar Hartlová.) 
ostatně nasvědčuje také druhý, výše publikovaný dopis z 18. 4. 1859, v němž Smetana Dreyschockovi popisem aktuální tragické rodinné situace odhaluje i své momentální citové rozpoložení a podrobnější vylíčení událostí zmiňovaných v dopise ponechává na budoucí osobní setkání. Dopis psal totiž v Dráždanech den před úmrtím své první manželky Kateřiny, kterou tehdy společně s tchýní Annou Kolářovou urychleně převážel z Göteborgu do Prahy. Zmínka o dvou Dreyschockem nezodpovězených dopisech však naznačuje, že komunikační aktivita asi vycházela více od Smetany, at’ z vděčnosti nebo ze snahy udržovat tento pro něho možná důležitý kontakt, navíc s někým, kdo trochu poznal göteborské poměry, zatímco Dreyschock potřebu se Smetanou komunikovat zřejmě neměl. Smetanovo zdůvodnění komplikovanějším chodem poštovních zásilek v zimních měsících lze vnímat nejen jako možný reálný důvod, ale i jako „diplomatické zahlazení" určité výtky v podtextu. Tuto jednostrannou nevyváženost do jisté míry potvrzují rovněž zmínky o poslední

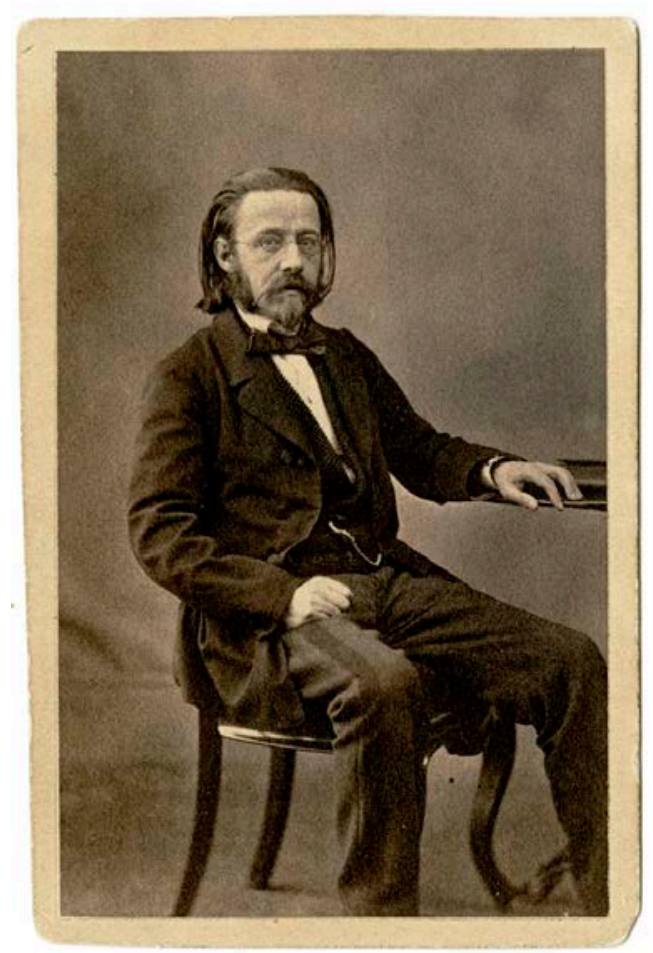

Bedřich Smetana (1824-1884)

Photograph, studio of M. Unna \& Höfferts, Gothenburg, [before 1860] / Fotografie, ateliér M. Unna \& Höfferts, Göteborg, [před 1860] NM-ČMH-MBS S 217/1729 doložené písemné komunikaci mezi oběma umělci z konce dubna 1862 (samotné dopisy jsou nezvěstné). Smetana tehdy pobýval od března do začátku května opět v Göteborgu, aby vylepšil svou finanční situaci, nebot’ po návratu do Prahy nenašel pevnou existenci a žil pouze ze švédských úspor. V Göteborgu vyučoval, uspořádal dva koncerty a plánoval koncertovat též v norské Christianii (= Oslo) a dánské Kodani. Ke konci svého pobytu, 27. dubna 1862, obdržel od Dreyschocka, který právě vystupoval v Kodani, ${ }^{17}$ dopis se žádostí o podporu při uspořádání jeho koncertu v Göteborgu: „Brief von Alex[ander] Dreyschock aus Kopenhagen, worin er seine Absicht nach Gothenburg zu Conzerten zu kommen ausspricht, und meine Unterstützung ersucht. ${ }^{₫ 8} \mathrm{~V}$ následujícím komentáři Smetana na jeho žádost reaguje dosti nevlídně: „Zu Hause in Prag kümmert er sich wenig um mich, er sieht aus stolzer Höhe seines Ruhmes auf mich herab. Indessen kann ich hier nichts thun, so gerne ich bereit dazu bin; aber ich konnte mir selbst nicht viel helfen, geschweige Anderen. ${ }^{\text {‘9 }}$ I když tato Smetanova

17) K Dreyschockovým koncertům v Kodani viz zpráva v Daliboru, roč. 5, 1862, č. 17, s. 128.

18) Smetanův deník 1861/62, 27. 4. 1862, s. 22 (NM-ČMH-MBS S 217/1099).

19) Smetana z Göteborgu odcestoval již okolo 3. května. Z dopisu Rosy Valentin Bettině Smetanové ze 4. 7. 1862 (NM-ČMH-MBS S 217/1970) víme, že Dreyschock přijel do Göteborgu až v červnu 1862, 12. června 
spontánní reakce zřejmě vystihla podstatu Dreyschockova vztahu k němu, je třeba vzhledem $\mathrm{k}$ přátelskému, do jisté míry až důvěrnému tónu obou jeho předchozích dopisů brát její vyhrocenost s určitou rezervou. V nepříznivých situacích Smetana totiž často reagoval nevybíravě a ne zcela objektivně a zde mohla roli sehrát jistá roztrpčenost z neúspěchu jeho původních koncertních plánů, nebot’ od svého záměru koncertovat v Kodani musel upustit proto, že zde ve stejném období měli již zarezervované termíny koncertů jiní, mnohem proslulejší umělci, mezi nimi i Dreyschock. ${ }^{20}$ A ani jeho vlastní koncerty v Göteborgu nedopadly návštěvností a finančně zcela podle jeho očekávání a s odvoláním na místní poměry také Dreyschockovi zřejmě odpověděl: „Antwort an Dreyschock geschickt, wobei ich die trostlosen Aspekten der Gothenburger mus[ikalischen] Zustände ihm schilderte. ${ }^{21}$

Zatímco Smetanův dopis Dreyschockovi z 18. dubna 1859 byl objevem pramene dosud neznámého, Smetanův dopis z 9. ledna 1882 adresovaný Pěveckému spolku Bivoj v Budyni nad Ohří, který se podařilo zakoupit v roce 2017, je po mnoha letech znovunalezeným originálem. Text dopisu byl již v roce 1885 publikován v časopise Dalibor, ${ }^{22}$ jenž v letech 1885-1887 průběžně uveřejnil výběr devadesáti pěti Smetanových dopisů, které redakci $\mathrm{k}$ tomuto účelu jejich tehdejší majitelé poskytli. Tento dopis byl zapůjčen př́mo spolkem Bivoj, o čemž svědčí přípis na f. $2^{\mathrm{r}}$ : „Slavná | redakce hud[ebního] časopisu |,Dalibor | v Praze | Račtež nám originál tohoto | listu laskavězpèt zase vratiti | vhluboké úctě| V. Nešvera|t[oho] č[asu] pokladnik ,Bivoje “. V rukopisném soupisu Smetanových dopisů ve Smetanově muzeu (viz pozn. 3) je sice tužková poznámka, že se dopis nachází v majetku spolku Bivoj, avšak nevíme, zda tehdy byla tato informace také prověřena. V roce 1960 po něm pátral Mirko Očadlík v rámci příprav svého soupisu Smetanových dopisů. ${ }^{23} \mathrm{Z}$ publikovaného soupisu je

vystoupil na početně nepř́liš navštíveném matiné a byl vřele přijat zejména v domech Smetanových zdejších nejbližších přátel: „[...] er war vier Tage hier, spielte viel bei Frau Benecke, auch mehre à quatre mains mit ihr, er sagte daß es ihm wohlthue zu hören wie beliebt Herr Smetana hier ist, er war auch bei uns, u[nd] probierte unser Instrument, mein Mann sagte ihm, daß er würde ihm gern, nur aus Dankbarkeit das Instrument leihen, weil er vor Jahren Herrn Smetana dazu überredete nach Gothenburg zu gehen."

20) Viz dopisy Lose, Carl Christian: Smetana, Bedřich, 9. 4. 1862; Smetana, Bedřich: Smetanová, Bettina, 11. - 19. 4. 1862 (NM-ČMH-MBS S 217/724 a 158; KBS I, s. 369-370, 372-379).

21) Smetanův deník 1861/62, 28. 4. 1862 (viz pozn. 18). Obdobně Dreyschockovu žádost komentuje i v dopise manželce Bettině z 24. - 30. 4. 1862 (KBS I, s. 386-387): „Alex. Dreyschock hat aus Kopenhagen an mich geschrieben, daß er herkommen will, um zu konzertiren, und ich möchte ihn durch Rath etc. unterstützen. Was kann ich thun? Ich bin froh, daß meine eigenen Conzerte so passabel ausfielen, und habe wenig Einfluß mehr auf die hiesigen Leute."

22) Smetanovy dopisy, Dalibor, roč. 7, 1885, č. 47, s. 459.

23) Na jeho dotaz se dochovala odpověd' z tehdejšího Jandova muzea v Budyni nad Ohř́: „,[...]V archivu našeho muzea dopis není. Mohl však býti v městském archivu. Když totiž Bivoj přerušil svoji činnost (již dávno), byly listiny a muzikálie Bivoje na popud archiváře Jandy uloženy v městském archivu. Při opětném zahájení činnosti byly mu věci z archivu zase vydány. Po letech činnost opět ustala, ale věci nebyly již uloženy do archivu. Zủstaly ve skříni v hostinci, kde měl Bivoj svoji místnost, a během Protektorátu ocitly se v místech, kde byly prístupny nezodpovědným lidem a neví se, kdo a jak jimi hospodařil. Teprve $r .1958$ členové muzejního kroužku přenesli, co ještě z nich zbývalo, do městského archivu. [...] $\vee$ tomto archivu je třeba hledat. Je možno, že archivář Janda, když vydával bivojské věci po prvém obnovení činnosti, vydal jen muzikálie a spisy ponechal v archivu." Uloženo v agendě k edici Smetanovy korespondence v MBS ad čj. 283/90 MČH 1. 
zřejmé, že se mu originál dohledat nepodařilo. ${ }^{24}$ A rovněž při prověřování provenienčních údajů v rámci př́prav kritické edice Smetanovy korespondence počátkem devadesátých let 20. století dostalo muzeum ohledně existence tohoto dopisu negativní odpověd. ${ }^{25}$

Dopis je napsán tmavým inkoustem na první straně dvojlistu dopisního papíru o rozměrech $230 \times 145 \mathrm{~mm}$, a to rukou Josefa Srba, Smetana jej jen vlastnoručně podepsal. ${ }^{26}$

„Slavnému výboru pèveckého spolku

$$
\begin{gathered}
\text {,Bivoj' } \\
\text { v Budyni! }
\end{gathered}
$$

Za zvláštní vyznamenání, jehož se mi dostalo tím, že slavný spolek ,Bivoj jmenoval mne svým čestným členem, vyslovuji diky nejsrdečnější.

Jest mi to tím větším potěšením, že pocty této dostalo se mi od spolku tak bujarého, vynikajíciho zdárnou činností v každém ohledu. Přeji slavnému spolku zdaru co nehojnějšiho a prosím, aby slavný výbor vyslovil veškerým pánum členům pozdrav muj srdečný!

$$
\text { S výslovnou úctou }
$$

V Praze 9. ledna 1882.

\section{Bedř. Smetana“}

Časově a obsahově spadá tento dopis do zcela jiného kontextu Smetanovy korespondence, která se do roku 1882 rozrostla co do objemu i obsahové různorodosti. Od Smetanova návratu ze Švédska do poloviny sedmdesátých let, tj. v době jeho nejintenzívnějších aktivit v pražském hudebním životě, stále ještě nebyly jeho písemné styky příliš rozsáhlé, nebot většinu osobních a pracovních záležitostí v Praze mohl vyřizovat osobně a také rodinná korespondence se omezila hlavně na letní období, které rodina trávila na venkově. Teprve po ohluchnutí (podzim 1874), kdy se písemný styk stal jediným způsobem jeho komunikace s nejbližším okolím i s veřejností, došlo k výraznému nárůstu Smetanovy korespondence, který kulminoval v osmdesátých letech. ${ }^{27}$ Tehdy již Smetana dosáhl postavení celonárodně uznávaného tvůrce české hudby a především u př́ležitosti některých oficiálních poct a oslavných akcí uspořádaných na jeho počest obdržel mnoho blahopřejných telegramů a dopisů. A právě tento typ korespondence významně přispěl k jejímu skokovému nárůstu v př́slušných letech. Udělení čestného členství, stvrzené v některých př́ípadech ještě předáním čestného diplomu, bylo poměrně častým projevem uznání a úcty různých institucí a zejména spolků zasloužilým osobnostem. Ve Smetanově pozůstalosti se dochovalo celkem 28 čestných

24) Očadlíkův soupis (viz pozn. 3), s. 100 uvádí, že dopis se nachází v archivu spolku Bivoj, avšak v současnosti je nedostupný.

25) Viz dopis z Okresního archivu v Litoměřicích se sídlem v Terezíně z 6. 12.1990: „Materiály fondu Zpěvácký spolek Bivoj Budyně n. O. jsou u nás uloženy. Zmiňovaný dopis však mezi nimi není, o jeho osudu nám není nic známo." Uloženo v agendě k edici Smetanovy korespondence v MBS ad čj. 283/90 MČH 1.

26) Do fondu Bedřich Smetana byl dopis zaevidován pod inv. číslem $S$ 217/2319.

27) $\vee$ letech 1863-1873 se podle aktuálního stavu dokumentace Smetanovy korespondence pohyboval celkový počet dnes známých korespondenčních sdělení v rozmezí 27-45 jednotek ročně, v roce 1874 je to již 84 jednotek, v období $1875-1879$ to je v rozmezí 67-125 jednotek ročně a v letech 1880-1882 je to 271, 221 a 244 korespondenčních sdělení. 

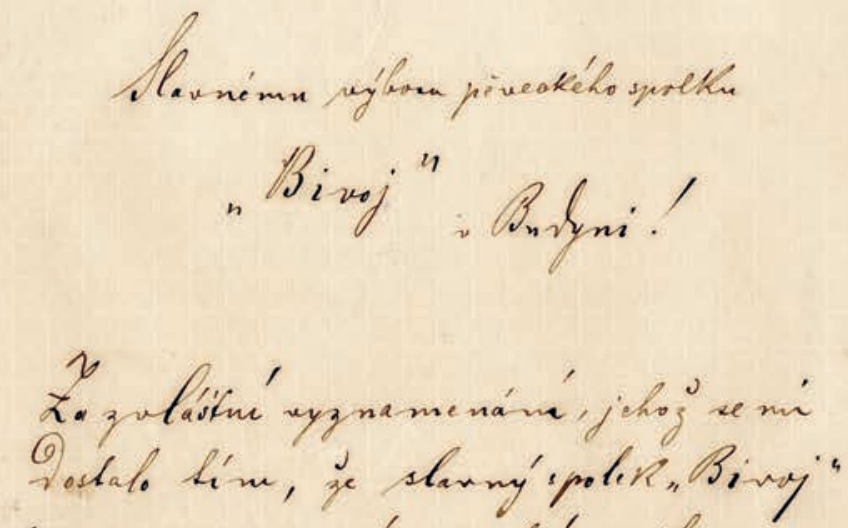

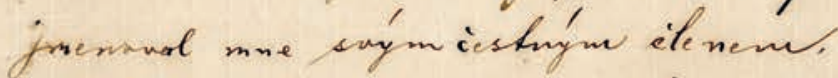

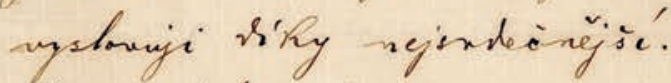

fest un tolim vetism poticienim, je pody

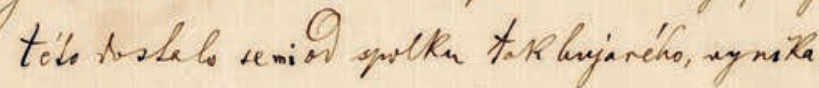

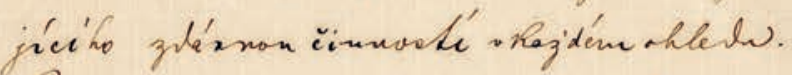

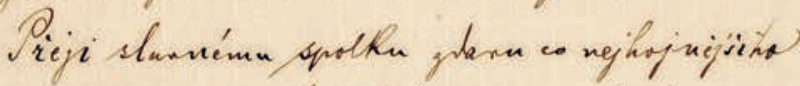

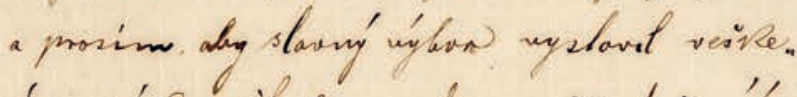

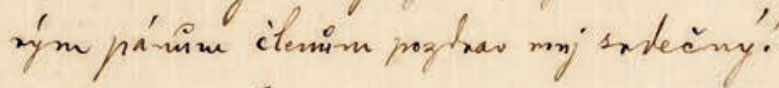

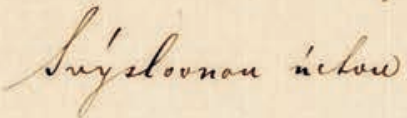

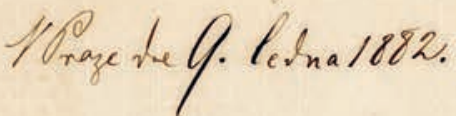

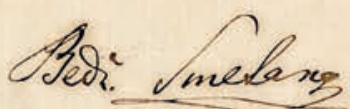

Bedřich Smetana to the Bivoj Vocal Society in Budyně nad Ohři /

Bedřich Smetana zpěváckému spolku Bivoj v Budyni nad Ohří

Autograph (Josef Srb, signature of B. Smetana), 9 Jan. 1882 /

Autograf (Josef Srb, podpis B. Smetana), 9. 1. 1882

NM-CMH-MBS S 217/2319 
diplomů, ${ }^{28}$ řada dalších spolků mu udělení čestného členství oznámila pouze písemnou formou. Tak tomu bylo také v prŕípadě spolku Bivoj v Budyni nad Ohří, který Smetanovi usnesení své valné hromady ${ }^{29}$ sdělil telegramem 31. prosince 1881: „Slovutný mistře! Valná hromada zpěváckého spolku ,Bivoje`v Budyně nad Ohři uznávajíc nehynoucí zásluhy Vaše o českou hudbu, jmenovala Vás jednohlasně čestným členem svým. Výbor Bivoje." ${ }^{\text {"So }}$ Smetanův dopis z 9. ledna je odpovědí na toto oznámení. Že bylo psáno a nepochybně i formulováno Josefem Srbem, nebylo v tomto období ničím mimořádným. Srb, u něhož Smetana za svých pobytů v Praze prakticky vždy bydlel, byl nejen jeho blízkým a důvěrným přítelem, ale částečně plnil též roli jeho osobního sekretáře. Smetanovým jménem přímo jednal a korespondoval s některými institucemi a z jeho pověření vyřizoval občas takovouto oficiální korespondenci, připravoval či korigoval mu texty některých jeho dopisů apod. Od 7. až do 28. ledna 1882 Smetana pobýval v Praze $^{31}$ a telegram z Budyně adresovaný do Jabkenic nepochybně přivezl s sebou k vyřízení a posléze tedy podepsal i Srbem naformulovanou odpověd'.

Jmenování čestným členem nebylo jediným projevem úcty a respektu budyňského Bivoje ke Smetanovi. V lednu 1880 zaslal blahopřejný telegram a přispěl částkou 10 zlatých do sbírky na čestný finanční dar u příležitosti slavnostního koncertu k 50. výročí Smetanovy koncertní činnosti, vyhlášené mezi českými spolky Uměleckou besedou, Hlaholem a Akademickým čtenářským spolkem. ${ }^{32}$ Blahoprejné telegramy zaslal rovněž 5 . května 1882 k 100. představení Prodané nevěsty a 2. března 1884 k Smetanovým 60. narozeninám, ${ }^{33} 13$. května následoval ještě soustrastný telegram ke Smetanovu úmrtí. ${ }^{34}$

Oba nově získané dopisy jsou významným obohacením stávajícího fondu Smetanovy korespondence. První rozšiřuje skromný objem skladatelových písemných styků z padesátých let a je důležitým dokladem jeho kontaktů s významnou osobností z tehdejších hudebních kruhů. Druhý dopis doplňuje bohatou kolekci korespondence související s oficiálními poctami, jichž se Smetanovi dostávalo na sklonku života. Oba nálezy pak dávají naději na případné další „objevy“ dnes nezvěstných či dosud neznámých dopisů, které by mohly kolekci Smetanovy odeslané i přijaté korespondence ještě rozšíritit.

Adresa: Olga Mojžíšová, Muzeum Bedřicha Smetany, Novotného lávka 1, 11000 Praha 1, Česká republika E-mail: olga_mojzisova@nm.cz

28) Tři diplomy obdržel již v šedesátých letech, 8 v sedmdesátých letech a 17 jich je z let 1880-1884.

29) Konala se 30. prosince 1881, viz Urbánkův Věstník bibliografický, roč. 3, 1882, č. 1, s. 9.

30) Originál v soukromém majetku, kopie v MBS č. př. 34/91.

31) Zápisky v kalendáři Vlast' na rok 1882, leden (NM-ČMH-MBS S 217/1123).

32) Viz tištěný výkaz všech příspěvků na čestný dar (Státní okresní archiv Semily, archiv zpěváckého spolku Jizeran). Více in: MOJŽÍŠOVÁ, Olga: Čestné finanční dary Bedřichu Smetanovi, in: Miscellanea z výroční konference České společnosti pro hudební vědu 2008. Fenomén mecenášství v hudební kultuře, Česká společnost pro hudební vědu - Etnologický ústav Akademie věd České republiky - Nakladatelství Agora, Praha 2010, s. 78-83.

33) Originály viz pozn. 30.

34) Viz soupis soustrastných telegramů z českých měst uveřejněný v Daliboru roč. 6, 1884, č. 20, s. 195. 